\title{
Physiological plant anatomy
}

An English translation of the fourth edition of HABERLANDT's Physiologische Pflanzenanatomie 3 will be welcomed by all who have been engaged in the study and teaching of this particular phase of the science, particularly as it will make the investigations of this leader in physiological anatomy more readily available for students. As pointed out by the translator, the latest German edition, recently reviewed in this journal, ${ }^{4}$ may be assumed to embody the mature and considered views of its author with regard to this section of botanical science. In the chapter on sense organs, in particular, there is much original data, now appearing for the first time in English. Here no one will question the facts presented, although many will object to the teleological interpretations given by HABERLANDT.

The translator seems to have done his work very well, at times using considerable freedom to obtain a desirable clearness of expression quite in keeping with the meaning of the original. The volume is well printed in a most legible type, and all the illustrations, notes, and bibliography of the German edition are retained. One might sometimes wish, however, for complete citations of the literature.-GEo. D. Fuller.

\section{MINOR NOTICES}

A northwestern manual. $-\mathrm{F}_{\mathrm{RYE}}$ and $\mathrm{RIGG}^{5}$ have prepared a manual for the use of schools of Oregon, Idaho, Washington, and the coastal region of southwestern British Columbia. These special manuals for relatively restricted regions are very useful for schools, since the keys can be made much more direct and simple, and the descriptions can be fitted more closely to the local conditions than is possible in manuals that cover a large area. The book is well organized, with every device for easy use, and should prove well adapted to its purpose. The real test of a manual lies in its use, and the reviewer cannot estimate this one from such a standpoint, but he has every reason to believe that the long experience of the authors in the region covered has enabled them to fit the work exactly to its purpose.-J. M. C.

Plantae Wilsonianae.-SARGENT ${ }^{6}$ in co-operation with several specialists has recently issued, as a fourth part of Plantae Wilsonianae, another important

3 Haberlandt, G., Physiological plant anatomy, translated from the 4th German edition by Montagu Drummond. 8vo. xv+777. figs. 29r. London: Macmillan. 1914. \$6.50.

4 Bот. GaZ. $55: 402$. I913.

${ }^{5}$ Frye, T. C., and RigG, G. B., Elementary flora of the Northwest. pp. ${ }_{25}^{6}$. New York, Cincinnati, and Chicago: American Book Co. I9r4.

${ }^{6}$ Sargent, Charles Sprague, Plantae Wilsonianae. An enumeration of the woody plants collected in western China for the Arnold Arboretum of Harvard University during the years 1907 , 1908, and I9ro by E. H. Wrison. Part IV. Publications of the Arnold Arboretum. no. 4, 8vo. pp. 262. Cambridge: The University Press. Issued March 24, I9I4. 


\section{$2 \mathrm{BHL}$ Biodiversity Heritage Library}

1915. "Physiological Plant AnatomyPhysiological Plant Anatomy, Translated from the 4th German.G. Haberlandt." Botanical gazette 59(1), 60-60. https://doi.org/10.1086/331470.

View This Item Online: https://www.biodiversitylibrary.org/item/109349

DOI: https://doi.org/10.1086/331470

Permalink: https://www.biodiversitylibrary.org/partpdf/223595

\section{Holding Institution}

Missouri Botanical Garden, Peter H. Raven Library

\section{Sponsored by}

Missouri Botanical Garden

\section{Copyright \& Reuse}

Copyright Status: Public domain. The BHL considers that this work is no longer under copyright protection.

This document was created from content at the Biodiversity Heritage Library, the world's largest open access digital library for biodiversity literature and archives. Visit BHL at https://www.biodiversitylibrary.org. 